\title{
Research on Professional View of Higher Vocational College Students
}

\author{
Haiyan Liu \\ Dalian University of Technology \\ Dalian, China 116024 \\ Dalian Vocational Technical College \\ Dalian, China 116035
}

\author{
Liansheng Yang \\ Dalian University of Technology \\ Dalian, China 116024
}

\begin{abstract}
Vocational education is an important part of national educational system and human resource development. The Party Central Committee and the State Council take vocational education as important foundation of economic and social development and strategic focus of education. However, some higher vocational college students have unpractical professional view because of being influenced by traditional employment view. Therefore, it is of great practical significance to deeply research professional view education for higher vocational college students, guide them to establish scientific and reasonable professional view, drive development of modern vocational education system, promote systematic cultivation of high quality technical and skilled talents, institutionalized accumulation of national technical skills and diversified growing path for talents.
\end{abstract}

Keywords-higher vocational college students; professional view; professional view education

\section{INTRODUCTION}

The teaching objective of higher vocational education is to cultivate numerous high quality technical and skilled talents who can meet the front-line requirements of production, construction, management and service. Therefore, higher vocational education shall pay more attention to cultivation of students' professional view. It has important guiding significance on professional learning, career choice and life development of higher vocational college students through guiding them to establish scientific and correct professional view as soon as possible.

\section{SCIENTIFIC CONNOTATION OF PROFESSIONAL VIEW OF Higher VocATIONAL COLLEGE STUDENTS}

Professional view of higher vocational college students refers to their attitudes toward occupation and the basic reflection of world outlook, outlook on life and values of higher vocational college students on occupation. Professional view has different levels because of different proportion, structure and function of "three factors of occupation" (make a living, develop individuality and undertake social responsibility) and plays a dominant role in students' jobhunting intention, working attitude and professional behavior. Students make concrete analysis and judgment on the nature and form of labor of a certain occupation, social status and development prospect, salary and interpersonal relationships of the occupational group and whether it conforms to their professional skills, talents, interests and characters and then summarize quality of the occupation. Professional view is the reflection of people's inner experience on occupational activity in their mind. It will influence all the effects that people work on occupational activities. Professional view has directly promoted effect on students' achievement at school and whether they can achieve teaching objectives. The core of professional view education is to help students to establish correct professional view. Professional view is a very complicated concept, including many contents. Therefore, correct professional view also involves contents of many aspects. The standard of professional view is different under different historical and social conditions. At present, establishment of correct professional view shall at least include the following aspects.

\section{A. Equal Professional View}

Legitimate occupations are necessary to create social wealth without lowliness and nobleness. No matter working on what kind of occupation, if one makes arduous efforts, he will make a difference. Mr. Huang Yanpei makes insightful annotation on equal professional view: Occupations are equal, without lowliness and nobleness. If an occupation is beneficial to people, it is the best. No matter manual labor or mental labor, simple labor or complex labor, they are the needs of occupational division of labor. There only exist different job categories. Some people in society blindly pursue high academic qualifications and high academic degree and think that regular higher education can cultivate cadres and "whitecollar workers" and higher vocational education will cultivate "blue-collar workers", so they look down on higher vocational education, which is because of traditional elite professional view. There are masters in every walk of life. Higher vocational college students shall abandon occupational bias, choose suitable occupations, make efforts to become talents and firmly believe that they can make a difference even on ordinary operating post.

\section{B. Independent Professional View}

Higher vocational college students can independently choose operating posts suitable for themselves according to characteristics of their own. Since the reform and opening up, 
the graduation assignment system for college students in our country changes from the united state plan for job assignment to "two-way selection and independent job selection". Graduates are freer to choose occupations. However, some college students do not completely change employment idea, even have the negative thinking of "waiting for, relying on and asking for", sit back and wait for the government, school and their family to arrange employment opportunities for them, or blindly follow others in hunting jobs. There isn't the best job but jobs that are the most suitable for us. The key is to understand ourselves and accurately position. Higher vocational college students shall make overall plans and take all factors into consideration such as employment situation, social needs, self-condition and career development, reasonably adjust employment expectation and choose jobs suitable for them.

\section{Professional View of Competition}

Higher vocational college students shall study hard and strive to improve technical skills and comprehensive quality, change employment idea and realize personal career development through market competition. In fierce competition, only those talents with relatively strong professional skills and relatively high comprehensive talents can stand out. Therefore, they shall continuously learn, accept new knowledge and new skills, master true skill and genuine knowledge, thus they can remain invincible all the time in the future employment competition. Some higher vocational college students pursue high income and stable working environment in the process of employment, lack sense of competition and fear hardships. Some graduates cannot correctly adjust employment expectation, which leads to the situation that their expected value seriously has no relationship with market demands, namely "they are unfit for a higher post but unwilling to take a lower one". Some graduates want to depend on others and lack independent sense of competition. Because higher education in our country transits from the stage of elite education to the stage of mass education, higher vocational college students face increasingly serious situation of employment competition. Therefore, college students shall establish professional view of competition. On one hand, they shall have the courage to compete and be good at competition, strive to live in competition and seek development in competition; on the other hand, they should strive to master skills, make active preparations, take the initiative and enhance confidence as well as unceasingly meet the needs of market.

\section{IMPORTANCE FOR HIGHER VOCATIONAL COLLEGES TO} STRENGTHEN PROFESSIONAL VIEW EDUCATION ON STUDENTS

\section{A. Help to Promote the Formation of Professional Ideal of Higher Vocational College Students}

The formation of professional ideal has to go through development processes of perceptual knowledge to rational knowledge, the abstract to the concrete and the unstable to the stable. Higher vocational college students are in the key stage of development of professional ideal. Their independent consciousness develops rapidly at this stage. They have certain ability of comprehensive analysis and reasoning ability of logical thinking. With increasing opportunities to get in touch with the society and further understanding for social occupation, they begin to explore their vocational prospects and evaluate the value of occupation. At this time, strengthening professional view education on higher vocational college students can help them to correctly analyze themselves, know the occupation and the society and make their professional ideal gradually become systematic and scientific and begin to make arduous efforts to realize professional ideal.

\section{B. Help Higher Vocational College Students to Establish Clear Life Goal}

Professional view is integration of personal pursuit of interest and service for the society. Career objective is to professionalize and crystallize life goals. With correct and reasonable professional view, college students will have clear objective of the struggle and accurate direction of life development. In the construction period of socialist cause with Chinese characteristics, under the condition of socialist market economy, higher vocational college students shall find clear struggling goals and correct development direction and accurately find out their operating post, thus they can make contributions to realize common ideal and lofty ideal of the whole society. Under the condition of market economy, "employment difficulty" has seriously influenced the establishment of ideal and faith of higher vocational college students. It is particularly important to face the new situation, strengthen professional view education, cultivate brand-new employment idea and establish the professional view to make contributions in ordinary post.

\section{Help Students to Scientifically and Reasonably Design Career}

Professional view is the mark to guide career development of higher vocational college students and the dynamic factor for a person to scientifically and reasonably design career. Only with clear professional ideal can higher vocational college students formulate scientific and reasonable development plan and put it into practice, in order to realize career objective. A reasonable and proper professional ideal can use huge emotional appeal to guide students to correctly choose an occupation, arouse their enthusiasm and courage to take up an occupation and make them make efforts to fight on the journey of achievement cause.

\section{Help to Improve Comprehensive Quality of Higher Vocational College Students}

Once forming reasonable professional view, students will consciously put it into practice. It makes people produce a strong will and emotion. If higher vocational college students have clear career objectives and determine employment direction in the future, they will connect today's learning with future professional achievements, integrate their life into national great cause and will not be confused about the quality of occupation, show strong desire to obtain knowledge, improve occupational skills and comprehensive quality, better cherish the learning time at school and make sufficient preparations for social role that they will work on in the future. 


\section{E. Help to Promote Effectiveness of Ideological and Political Education on College Students}

Higher vocational education is employment oriented higher education. For the function of ideological and political education, except for common goal, content and way just as undergraduate education, its unique connotation can be interpreted as: make higher vocational college students strengthen the political faith to construct socialism with Chinese characteristics, make them have lofty professional ideal, good professional ethics, consciously abide by professional discipline and professional regulations, easy to cooperate with others, serve the people wholeheartedly; it pays attention to professional consciousness, professional ideal, professional ethics and education on employment view as well as view of entrepreneurship. These connotations of ideological and political education reflect the fundamental objective of ideological and political education in higher vocational colleges is to guide students to develop healthily according to social needs in the future and personality characteristics.

\section{BASIC CONTENTS AND WAYS FOR HIGHER VocAtional COLLEGES TO STRENGTHEN PROFESSIONAL VIEW EDUCATION ON STUDENTS}

\section{A. Basic Contents of Professional View Education on Students in Higher Vocational Colleges}

1) Impart vocational knowledge to students: Students' personal vocational ability cannot do without learning and accumulation of related vocational knowledge. Strengthening education on vocational knowledge for students, such as teach students how to write job application letter, the art of job interview and workplace skills, can not only make students fully understand professional knowledge learned by them but also apply professional knowledge, set career objectives according to their vocational ability and lay good foundation to improve students' comprehensive ability.

2) Cultivate students' vocational ability: Vocational ability refers to the abilities of people to use their knowledge, give play to various potentials and finish occupational activities in the process of working on certain activity. Intensifying the cultivation of students' professional ability can help students to accumulate knowledge and improve their professional practical abilities as well as professional attitude and working ability.

3) Cultivate students' professional ethics: Professional ethics refer to the code of conduct that conforms to occupational activity and should be followed by people working on certain occupation in the process of working or labor. Strengthen the cultivation of professional ethics for higher vocational college students, make students' thoughts more conform to the construction of socialist cause with Chinese characteristics, better devote to the cause of socialist modern construction, let students learn to become person who "cherish posts and wholeheartedly to work, with honesty and trustworthiness" and make contributions to the society.
4) Train students' ability to grasp employment information: After helping students to know about the society and occupation, timely and correctly grasp national employment situation and employment information, let students timely know the change of market resource of labor force, employment situation and development tendency in our country, help students to better make corresponding adjustment on learning life and career planning.

\section{B. Main Paths of Professional View Education on Higher Vocational College Students}

The professional view education of higher vocational colleges shall run through the whole process of talent training. Since the first day when students enter the university campus, it is necessary to pay high attention to the establishment, training and promotion of professional view and let professional view education run through three years of learning and put it into practice.

1) Positively carry out formative education of higher vocational college students, establish scientific and reasonable professional view: In entrance education of freshmen, professional view education shall be regarded as the important content and core link of students' ideological and political education. Define learning objectives, positively carry out professional education, education on school discipline and school regulations, education in standards of behavior and safety education and continuously improve professional ability, cultural literacy, physical and mental quality as well as practical ability through activities such as career planning, course arrangement, simple etiquette training, mental health education and voluntary service. Help higher vocational college students further know about vocational situation and vocational prospects, improve occupational qualities, train professional ethics, firm professional ideal, further stimulate senses of identity and pride of higher vocational college students on occupations and establish correct professional view.

2) Bring professional view education into the whole process of education and teaching by taking classroom teaching as the platform: In professional teaching, it needs to mention the relationship between "specialty and occupation", center on professional view education, open courses such as "occupational career planning of college students", let professional view education run through the training process of high quality technical and skilled talents, as well as the process of professional learning and quality enhancement of higher vocational college students. Pay equal attention to theoretical teaching and practice examination. Continuously exert the role of main channel of classroom teaching, bring theoretical teaching into classroom teaching through ways such as case analysis, classroom simulation, discussion and communication as well as investigation to lay sold theoretical foundation for professional view education. Besides, professional view education shall continuously improve practical ability of college students through further taking 
practical activities as the platform such as campus practice, entrepreneurial practice and campus recruitment.

3) Let professional view education run through the whole process of technical and skilled talents training through employment guidance: During practical training inside school and substituted post exercitation, take occupational safety education, career counseling and return visit of excellent schoolfellows as carriers, unceasingly train consciousness of dedication, consciousness of responsibility and sense of mission of higher vocational college students and then establish correct professional view. Guide them to consciously obtain employment and start up business in firstline enterprises through ways such as substituted post exercitation, professional practice and enterprise internship and then finish the role change from students to social professional people.

\section{REFERENCES}

[1] Zhang Jizhong, Wu Zhi. Analysis on Strengthening Students' Professional View Education Implemented by Higher Vocational Colleges [J], Journal of Changchun Education Institute, 2013(24)

[2] Liu Min, Zhang Yihui. Research on Problems of Professional View Education for Higher Vocational College Students [J], Vocational Education Research, 2011(01)

[3] Hu Fengju. Discussion on Professional View Research for Higher Vocational College Students [J], Science and Technology Information, 2007(06) 